\title{
A Discussion on the Teaching of Basis of Computer Engineering in PE Major in Colleges and Universities
}

\author{
Tan Xiaobo \\ PE Department, Jiujiang University, Jiujiang 332000, China
}

\begin{abstract}
With the wide application of the computer, it has been integrated into the professional fields of all kinds of industry, which also means that requirements for the education of Basis of Computer Engineering in colleges and universities have become higher and higher. This thesis makes an analysis of problems and phenomena existing in the teaching of PE major in colleges and universities, and then makes a discussion on the educational reform of Basis of Computer Engineering.

Index Terms - Education of Basis of Computer Engineering, Composite Talents of PE and Computer, Discussion
\end{abstract}

\section{Introduction}

With the rapid development of the computer, it is more and more applied to all walks of life. So, in this new situation, requirements for the new generation's computer knowledge and application skills have become higher and higher. Computer education of the students of PE major should also conform to the major features, to help students combine the basic computer knowledge with their expertise, so as to meet the social demand for talents. At present, most colleges and universities have set up the course of "Basis of Computer Engineering", but it is just an ordinary public compulsory course with no concern about the teaching methods and teaching contents. Schools generally adopt the teaching method of natural classes, in which all the students in different degree sit together and learn the course together. Some colleges and universities even mix students of different majors in the same class to have this course. Due to the particularity of the PE major and the difference of students' growth environment, their understanding of the computer and the actual operation levels are also different from each other. Therefore, this hybrid teaching method will have some influences on the teaching and students' learning effects.

\section{Problems Existing in the Current Teaching of PE Major in Colleges and Universities}

\section{A. Single teaching contents fail to meet the demand of PE major}

For PE major students, the purpose of learning the computer is able to pass the computer grade examination in order to get a diploma. Of course, this can provide an incentive to non-computer science students learn computer, But out of touch with the professional teaching basic computer teaching can not meet the demand for professionals in sports. Students will just use the computer, there is no contact with the professional, Students' comprehensive application ability has not been improved. Because the information technology development too fast, Talent market and employing unit not only requirement on word processing and data processing have higher ability, also requires the ability to do they have a basic system installation and maintenance, and even still can ask to analyze data, multimedia technology.

\section{B. students' mastery degree of the computer knowledge is uneven}

The computer has been popular for many years in our country. Middle school in our country has opened the computer basic courses. Because of the computer courses not included in the university entrance exam courses, Most of middle school to the attention of the computer courses also is different. Because of the different growth environment, some rural students almost didn't operating computer, do not know computer operating systems and some commonly used software, According to the computer society popularity in recent years. the number part of the students is less and less. Although the majority of students to learn computer knowledge, but only can browse the web, online games, QQ chat and email applications.

\section{Teaching effects with multi-media teaching are mixed}

Many universities now use multi-media teaching, Although the multi-media teaching has the characteristic of intuitive, image, vivid color, but teaching speed is much faster than the traditional teaching in a school hour. Computer foundation weak students have no time to understand, and has been in a passive situation, removing study enthusiasm.

\section{Too many teaching contents, but too few class hours}

The course content includes basic computer knowledge (history of the development and computer systems), as well as office automation software OFFICE, network architecture, information technology, $\mathrm{C}$ language program design. At present, the course of Basis of Computer Engineering has the following problems that the knowledge points are too many, the teaching contents have no obvious key points, and the students are required to learn a lot of knowledge that has no distinction of importance. Undergraduate students of PE major in our school now have 4 class hours every week for the learning of this course, and the junior college students of PE major have 3 class hours every week. As it's just a public compulsory course for non-computer majors' students, the school pays insufficient attention to it with too many teaching contents and too few class hours, and the proportion of the theory teaching time and practice teaching time is 1 to 1 , or even 2 to 1 . In order to finish the teaching task in time, many teachers pay much more attention to exams than the real 
practice by giving classes according to requirements of the final exam and computer grade examination outline. This teaching method greatly influences the learning initiative of the students, who reflect that they always clearly understand the theory classes, but can not remember the operation skills when having the practicing classes, because this course has no reasoning and calculation parts, needing only real practice and operation.

\section{E. Students' characteristics of PE major are particular}

According to my several years of teaching experience, I can evidently distinguish the different learning effects between PE major students and other majors' students. Because students of PE major tend to be more active and lively, and their ability of logic analysis is also weaker, they always don't feel so interested in the theory classes that the theory teaching effects are not that good. Furthermore, due to the excessive teaching contents and the traditional teaching method, teachers always just give lessons about the theoretical knowledge without too much interaction with the students or consideration of students' self-abilities and acceptance levels, so that students feel less and less interested in the course, but tend to disregard it and do their own things in the class or even skip the class.

\section{Discussions on the Teaching Mode}

A. Change the concept of valuing the computer rank examinations, and set up a reasonable curriculum system

At present, students from many colleges and universities attach too much importance to the computer grade examination. The schools even use the so-called "pass rate" to measure teachers' teaching effects, so that most of teachers just give lessons according to the exam outline without meeting the demand of students of PE major, which is bad to the cultivation of composite talents of $\mathrm{PE}$ and computer science. Therefore, it's pretty important to release teachers' pressure of the "pass rate". Schools should set up the course according to students' specialties and computer levels, so that teachers can have enough space to encourage students to solve practical problems and help them further master the comprehensive knowledge of computer. In addition, schools need to set up the curriculum system according to the needs of the majors and categories, and to focus on practical applications in the hierarchical teaching methods. The first hierarchy is the "foundational module", including the teaching of the basic knowledge of computer, basic understanding of the microcomputer composition, the operation of the operating system and the application of the office automation software; the second hierarchy is the "professional module", which refers to the teaching of the professional knowledge according to the demand of students of different specialties.

\section{$B$. Increase the proportion of practice}

Also, schools should increase the proportion of practical classes. In our school, the teaching mode is fixed of two theoretical classes and two computer operation classes, in which there're nearly 80 students and one teacher in the same computer classroom. The teaching effects of this teaching mode are not that good because it's a course with high requirements for students' operation abilities. Especially when teaching the synthetic operation skills, teachers actually need to provide more time for students to conduct real practice. So the best teaching method is to let the teachers arrange the practical class time freely, and to add more professional teachers for the class. If there are 2 or 3 teachers in one practical class, students may have more time to ask them for consultations.

\section{Break the limits of fixed classes, and adopt grade teaching method after evaluating students' computer skills and abilities}

Because of the unevenness of students' original computer levels and operation abilities, the teaching method of "one size fits all" in the computer course will increase the polarization of students' computer learning abilities. Students with good foundation may feel that learning computer skills is a waste of time, but the students with bad foundation may feel hard in the computer class and tend to give it up. This polarization will have a large handicap to the development of basic computer education in colleges and universities. So, I Suggest that schools should arrange a computer level test for the freshmen and adopt the hierarchical teaching methods according to the test results, so that teachers can get to know students' computer level and according to which, they can adjust their teaching syllabus and teaching schedules In addition, students can also check their computer levels through the test, understand their own shortcomings, and fully mobilize the enthusiasm of the future computer learning. The implementation of computer hierarchical teaching methods can optimize the teaching structure and teaching tasks, and improve students' comprehensive level of computer application.

\section{Update the evaluation mode}

Many schools adopt both the written exam and the computer operation exam. The former one includes multiplechoice questions, blanks filling and true or false questions. Some schools even adopt only the written exam due to a lack of computer classrooms, which is absolutely against the course requirements of not only understanding the basic theoretical knowledge, but also having the proficient computer operation skills. A simple written test can not complete the task of assessing students' computer skills. So I suggest that schools can imitate the test mode of the Computer Rank Examination to get rid of the written exam and adopt the computer operation exam with limited operation time.

\section{Conclusion}

The computer has become one of the basic tools in many fields, including the sports field, in which the professionals with computer operation skills are needed for the sports competitions and sports training. Therefore, the PE departments in colleges and universities should intensify 
efforts to strengthen the cultivation of talents in sports and computer science, improve the comprehensive quality of PE professionals by setting up the course of Basis of Computer Engineering. It can be said that in the computer era, mastering the basic computer operation skill is also a survival need. And the education of computer basis will become more and more important in higher education. Therefore, it has higher requirements for our teachers of how to improve the teaching skills of computer basis in the new situation, and how to enable students to not only master the basic computer knowledge, but also improve their operation skills to become comprehensive talents in sports and computer science, by deepening the educational reform. In the future teaching work, we also need to cultivate more efficient and high-quality teachers to constantly update training targets, teaching methods and teaching contents, so as to meet the requirement for comprehensive talents in the new social situation.

\section{References}

[1] Liu Jianli. Conduct the Educational Reform of Basis of Computer Engineering by Making Full Use of the Existing Teacher Resources. Computer Education, 2006(03).

[2] Li Haiyan. A Discussion on the Educational Reform of Basis of Computer Engineering in Non-computer Majors in Colleges and Universities. Modern Enterprise Education, 2006(17).

[3] Lu Xingfu. Analyses of the Status Quo and Reform of the College Computer Education. Journal of Chinese Science and Technology Innovation, 2010(10):183. 